\title{
The valorization of architectural heritage from the Ottoman Period in the Sarajevo Tourist Region
}

\section{Saraybosna Turist-Coğrafi Bölgesi’nde Osmanlı Dönemi mimari mirasının değerlendirilmesi}

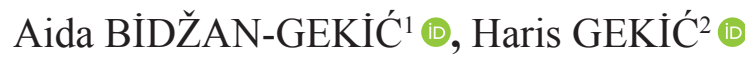 \\ ${ }^{1}$ University of Sarajevo, Faculty of Science, Department of Geography, Sarajevo, Bosnia and Herzegovina \\ ${ }^{2}$ University of Sarajevo, Faculty of Science, Department of Geography, Sarajevo, Bosnia and Herzegovina
}

ORCID: A.B.G. 0000-0002-3980-9750; H.G. 0000-0002-7055-6608

\begin{abstract}
The Sarajevo tourist region is extremely rich in architectural heritage with touristic value from the Ottoman period. In this area, Baščaršija and its surroundings can be distinguished in particular, featuring many Islamic residential and sacral objects. If cultural and religious events are to be included in this valorization, we can safely speak of an enormous tourist potential for this tourism region. It is the center for cultural tourism, not only in this area but also throughout Bosnia and Herzegovina and even beyond. This paper presents the most important objects of architectural heritage and the events that took place in them in the Sarajevo tourist region, their valorization, and their potential for exploitation for tourist purposes. Moreover, tourist traffic and the accommodation capacity of this tourism region are presented. Finally, conclusions are drawn regarding how these unique yet poorly protected and exploited phenomena can be managed to allow them to remain the same for future generations.
\end{abstract}

Keywords: Sarajevo tourist region, valorization, architectural heritage.

\section{öz}

Saraybosna turizm-coğrafi bölgesi, Başçarşı ve çevresinde özellikle ayırt edilebilecek turistik amaçlarla değerlenebilen Osmanlı döneminden kalma mimari miras bakımından oldukça zengin, pek çok İslami-oryantal konut ve sakral binalar bulunmaktadır. Kültürel ve dini programlar bu değerlemeye dahil edilirse bu turistik-coğrafi bölgenin sahip olduğu muazzam turizm potansiyeli konusunda kesin olarak konuşmak mümkündür. Aslında burası sadece bu bölgenin değil tüm Bosna-Hersek'in ve çevresinin kültürel turizmin merkezidir. Bu makale, mimari mirasın en önemli eserleri ile Saraybosna turizm-coğrafi bölgesinin içinde düzenlenen kültür programları değerlenmesini ve turistik potansiyellerini sunacaktır. Ayrıca, bu turistik coğrafi bölgenin turist trafiği ve konaklama kapasiteleri de gösterilecektir. Ve nihayetinde, gelecek nesillere bırakabilmesi için bu eşsiz, hâlâ yeterince korunmayan ve kullanılmayan fenomenlere nasıl davranılması gerektiği sonucuna varılacaktır.

Anahtar Kelimeler: Saraybosna turist-coğrafi bölgesi, değerlendirme, mimari miras. 


\section{INTRODUCTION}

The main difference between culture and heritage is that the culture is based on what the people create whereas the heritage is what the people inherit by nature, by history, by culture.

Culture is the characteristics and knowledge of a particular group of people, encompassing language, religion, cuisine, social habits, music and arts. Culture refers to the ideas, customs, and social behavior of a particular people or society. Thus, it encompasses every aspect in the way of life in people. It includes human values, beliefs, customs, languages, and traditions. Culture is reflected in the manner how people express ideas and creativity, their history as well as in the heritage (Zimmermann, 2017; O’Neil, 2006).

The Oxford English Dictionary defines 'heritage' as 'property that is or may be inherited; an inheritance', 'valued things such as historic buildings that have been passed down from previous generations', and 'relating to things of historic or cultural value that are worthy of preservation'. The emphasis on inheritance and conservation is important here, as is the focus on 'property', 'things' or 'buildings. So anyway, heritage is something that can be passed from one generation to the next, something that can be conserved or inherited, and something that has historic or cultural value. Heritage might be understood to be a physical 'object': a piece of property, a building or a place that is able to be 'owned' and 'passed on' to someone else (Lowenthal, 2019).

According to the Law on the Protection of the use of cultural-historical and natural heritage, real estate and movable property and their groups and units of special cultural and historical significance are considered as cultural and historical heritage. According to the basic characteristics and their origin of goods of cultural and historical heritage are:

- monuments of culture, monumental ensembles, archaeological sites, memorials and other goods defined by this law;

- works in the field of art and applied arts, crafts, technology, museum material, archival material, valuable libraries, old and rare books, films and film materials. Goods of cultural-historical and natural heritage, as well as goods of general interest enjoy special protection and are used under conditions and in the manner prescribed by law (Law of protect and use of historic-cultural and natural heritage, 2016).

Cultural heritage is an expression of the ways of living, developed by a community and passed on from generation to generation, including customs, practices, places, objects, artistic expressions and values. Cultural heritage is often expressed as either intangible or tangible cultural heritage (ICOMOS, 2002).

In modern civilization, the architectural heritage has an invaluable value. It is the irreplaceable identity of material and spiritual culture of every nation and it determines the appearance of cities and landscapes. The architectural heritage is defined by the Granada Convention (CEO, 1985), which includes ${ }^{1}$ :

1. Monuments: all buildings (of historical, archeological, artistic, social or technical significance) together with their equipment;

2. Groups of buildings: homogeneous groups of urban or rural buildings (of historical, archaeological, artistic, social or technical significance) that form distinguished topographic units;

3. Areas: built zones formed by the collective action of man and nature, which due to their specificity may be topographically defined (of historical, archeological, artistic, social or technical significance) (CEO, 1985).

Cultural heritage implies a shared bond, our belonging to a community. It represents our history and our identity; our bond to the past, to our present, and the future. Cultural heritage is the legacy of physical artefacts and intangible attributes of a group or society that are inherited from past generations, maintained in the present and bestowed for the benefit of future generations (UNESCO, 1972). In an era of globalization, cultural heritage helps us to remember our cultural diversity, and its understanding develops mutual respect and renewed dialogue amongst different cultures.

1 Convention for the protection of the architectural heritage of Europe (Granada, 3.10.1985) 
With the arrival of the Ottoman Empire in the XV century, the period of new urban and communal development of cities began for the medieval Bosnian state, ie changes in religious, linguistic, cultural, political and military aspects, which certainly reflected on the construction industry. Larger Bosnian-Herzegovinian cities (Sarajevo, Visoko, Tešanj, Mostar, Konjic, Travnik, Tuzla and others) that were created in the Ottoman urban tradition, which is marked as an Ottoman-Byzantine type of city consisting of two parts: čaršija ${ }^{2}$ (bazaar) - business part of the city and mahale ${ }^{3}$ - residential parts of the city (Bidžan-Gekić et al, 2017).

There are wooden shops (trade and crafts shops) in Sarajevo bazaar (Figure 1), with characteristic wooden shutters, where all the commercial work was done. Trade and crafts shops are concentrated in streets by types of shops or crafts and the streets carry their names (Kazandžiluk, Kujundžiluk, Ćurćiluk, Bravadžiluk, Kovači, Sarači, Mudželiti, etc.). Moreover, Sarajevo got bezistans, which in their time played the role of today's shopping centers.

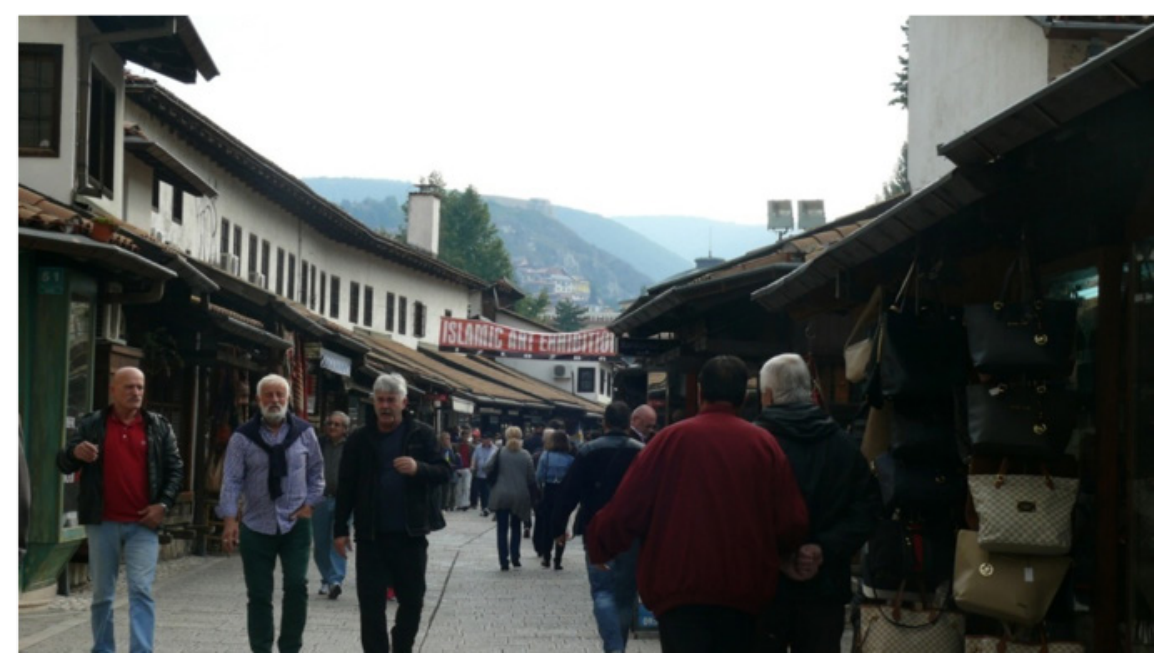

Figure 1: Baščaršija - the heart of Sarajevo’s tourist-geographical region

(Photo: author)

Outside the čaršija, there are mahale (Vratnik, Kovači, Bistrik, Alifakovac (Figure 2), Čemaluša, Dženetić Mahala, Bjelave ravne, Strošić, Hrid, Širokača sokak, Abdesthana etc.), which are the main city blocks and are intended exclusively for housing. In them there are houses, mostly two-storey houses whose first floor is positioned above the ground floor partially or completely, with a high-walled or wooden fenced courtyard. Each mahala had in its center a smaller mosque or a mesjid (a Muslim place of worship without a minaret), a fountain, a harem, a bakery, a grocery store, all serving the needs of forty to fifty individual family houses. Mahale had an inherent cult of the neighbours, regardless of national or religious affiliation. Today, only some peripheral local areas are called mahalas, and there were many more once.

2 The bazaar (craft and trade part of the city) is typically characterized by specific architectural qualities that make it recognizable in the entire city complex and reflects the identity or spirit of the city with its specifics. Basic elements of the Bosnian-Herzegovinian bazaar are mainly shops, crafts shops, mosques, churches, synagogues, tower clock, streets with shops and fountains. In traditional bazaars there were hammams, vakufnames, city administration and other objects of major importance to the city (Redžić, 1983).

3 Mahala is a village, quart, city district (sometimes a village district), a specific form within which people live in the cities of the Balkans and the Middle East. The word has a wider meaning than a group of houses. It also means the way of life, consciousness, the form of social relations. It has its psychological, social, economic, and many other meanings "(Redžić, 1983). 


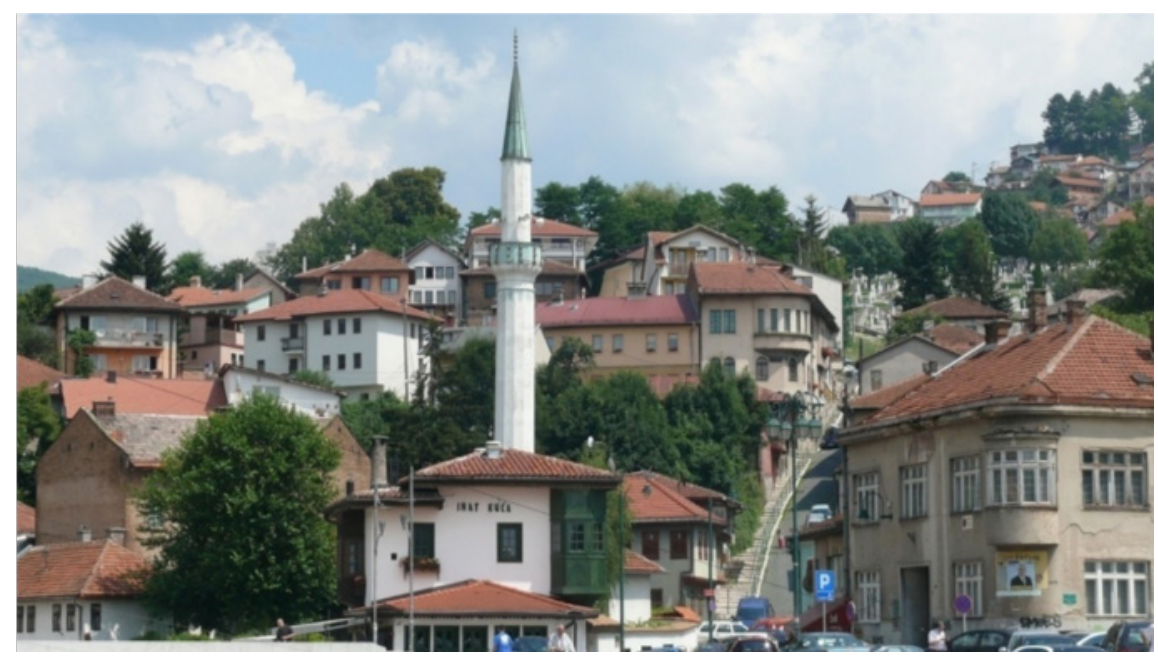

Figure 2: Inat house and Alifakovac mahala in Sarajevo (Photo: author)

\section{THE AIM and METHODOLOGY of RESEARCH}

The aim of this paper is to give an overview of the most important architectural tourism potentials from the Ottoman period in Sarajevo tourist-geographic region and the possibility of their valorization, which would contribute to the development of cultural tourism as well as the overall economic development.

The resource basis of contemporary cultural tourism in the Sarajevo tourist-geographic region has to be methodologically elaborated on the basis of geographic, economic and socio-cultural research, in order to obtain a complete potential tourist image that could, through the adoption of a proper tourism development strategy, be transformed into a real and sustainable tourism offer in whose focus would be the development of cultural tourism, which would further generate revenues for the preservation and restoration of this unique value of Sarajevo (Bidžan, 2012). In this paper, the following general and special methods of regional geographic research will be used: the method of regional geographic analysis and synthesis of tourism geographic factors, the method of homogeneity in the spatial distribution of tourism-geographic parameters in order to identify the architectural heritage of the Sarajevo tourist-geographic region, the method of establishment of spatialfunctional relationships and relationships primarily related to tourism activity in order to develop it better and to less disturb the environment.

In the process of valorization architectural heritage as an anthropogenic tourism potential related to the development of cultural tourism, different tourism-geographic methods and valorization factors will be applied, with a very complex classification procedure (identification and analysis of attractive properties, spatial coverage, arrangement etc.) and categorization / ranking of tourism potentials (by importance, seasonality, complementarity, etc.), whereby the overall tourist value of each selected tourism potential will be given. These anthropogenic tourist potentials are then divided into two groups, namely: real and potential tourist potentials, whereby in this paper only real ones will be shown due to a large number. When evaluating, special attention was paid to their complementarity, the suitability of their tourist-geographic position in relation to broadcasting markets, tourist directions and competitive receptive areas, as well as existing and potential traffic routes which allow access to broadcasting areas, etc. Method of identification, valorization and ranking of architectural heritage is based on the following criteria:

- That these are the most reputable examples of sacral, public, residential or memorial monuments of architectural heritage created in the Ottoman period;

- That these are monuments of architectural heritage that represent top architectural works, unique, rare and representative examples of monuments of a certain style of construction;

- That these are monuments of architectural heritage with high artistic or aesthetic value expressed through the richly decorated interior and exterior, the value of the movable heritage (valuable books, paintings, inscriptions, fragments of buildings, handicrafts or other objects) etc.; 
- That these are monuments of architectural heritage that have an ambient value indicating that a monument or group of monuments with its spatial position has a significant role in the image and structure of the city;

- That they have a historical value that may be related to a historical personality or a significant event in history;

- That they have documentary, scientific, educational or symbolic value, etc. (Bidžan, 2015).

This detailed and complex analysis, classification and categorization of architectural heritage as an anthropogenic tourism potential was made possible thanks to professional and scientific literature, consisting of spatial plans at the state, entity, cantonal and municipal levels, then development plans and strategies (economic and tourist) of cantons and municipalities, official web sites of municipalities and tourist communities as well as their own field research.

\section{SARAJEVO TOURIST-GEOGRAPHICAL REGION}

The Sarajevo tourist-geographic region is located in the Sarajevo valley that connects along the Bosnia river valley with the Danube and Central Europe in the north, and along the Neretva river valley with the Adriatic Sea and the Mediterranean in the south. The touristgeographical position of this region is very favorable because it has the capital of Bosnia and Herzegovina (Figure 3 ), which tourists are happy to visit. Moreover, the most important state roads go through it as well as the international airport, which all increase the significance of its tourist-geographic position, and after the construction of the Corridor Vc its position will even further improve (Bidžan, 2015). It occupies an area of $1,406.5 \mathrm{~km}^{2}$. The Sarajevo tourist-geographic region consists of four urban municipalities: Stari Grad, Centar, Novo Sarajevo, Novi Grad and five other suburban municipalities: Ilidža, Trnovo - FB\&H, Trnovo - RS, Hadžići, Vogošća and Ilijaš. Preliminary number of inhabitants according to the 2013 census is 440.635 , and the density of the population of this region is $313.3 \mathrm{resident} / \mathrm{km} 2$ (Institute for Statistics of the Federation of Bosnia and Herzegovina, 2013).

This tourist-geographical region is located in the eastern part of homonymous valley in the central part of the Dinaric mountain system of Bosnia and Herzegovina, in the interior depression distinguished as the Sarajevo valley. The relief is predominantly mountainous (over $700 \mathrm{~m}$ ), making up about $78 \%$ of the surface of this region, then hilly (550 - $700 \mathrm{~m}$ ) making 13\% and low (up to $550 \mathrm{~m}$ ) with $9 \%$. Sarajevo tourist-geographical region is located in the easternmost part of the Sarajevo valley, in the extended valley of the Miljacka River and on the mountainous slopes that descend towards it. The lowest altitude is in the area of Reljevo (460 m), while towards southeast and southwest elevation increases and reaches the maximum at Bjelašnica $(2,067 \mathrm{~m})$. The average altitude of Sarajevo is $537 \mathrm{~m}$. The valley stretches from northeast to southwest and has an area of about $32 \mathrm{~km}^{2}$. In the edge of the Sarajevo valley are elevations Žuč, Hum, Kobilja glava, Betanija, Breka, Sedrenik, Bistrik, Vraca, Mojmilo and others. In their hinterland spread the Olympic mountains: Bjelašnica, Igman and Trebević, which are, especially during the winter months, favorite destination of not only people of Sarajevo, but also their guests from all over the world. Also, we should not forget to mention that there are several significant speleological sites in this region (Bijambare, Megara, Klokočevica, etc.). Moderately warm and humid climate is prevalent in the area of this region up to $750 \mathrm{~m}$. Areas between 750 and $1.700 \mathrm{~m}$ have a forest-snowy climate, while areas with altitude above $1.700 \mathrm{~m}$ have a climate of tundra. Average annual air temperatures range from 6 to $10^{\circ} \mathrm{C}$. This region averages an annual precipitation of 900-1250 mm per year. It has a dense river network belonging to the Bosnia river basin, and its largest tributaries are the Miljacka and Željeznica (Atlas of the World for Primary and Secondary Schools, 1998). In a biogeographic view, three ecosystems are present in this region: mesophilic forests of sessile oak and common hornbeam, thermophilic beech forests and dark coniferous forests (Lakušić, 1981). 


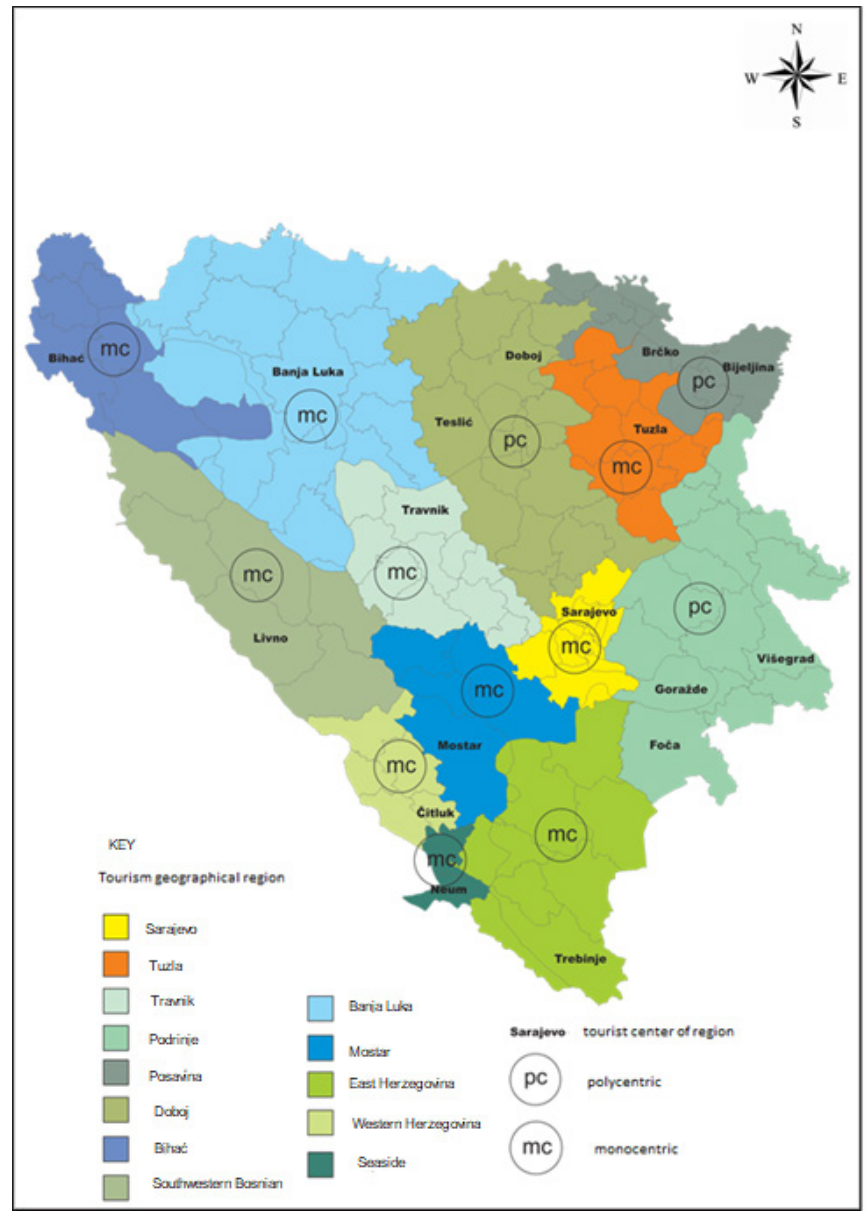

Figure 3: Tourist-geographic regions of Bosnia and Herzegovina (Source: Bidžan, 2012)

Sarajevo tourist-geographical region has been inhabited since the end of the New Stone Age. From around 2400 till 2000 BC, there was a Neolithic settlement in Butmir, in the western part of the Sarajevo valley. This area was inhabited even in the Metal age - in the 2nd and 1st millennium BC. These are also localities in the western and southern parts of the Sarajevo valley - Illyrian settlements Gradac near Butmir and Naklo on the left bank of the Željeznica, as well as on the slopes of Trebević - Illyrian fortified settlements, the forts: Debelo brdo, Soukbunar and Zlatište. At Debelo brdo, the Romans built their fort, and around the warm sulfur springs in today's Ilidza area, they founded and developed the urban agglomeration called Aqua S. In the Middle Ages, the Sarajevo area was part of the Vrhbosna parish. Already in that period Sarajevo was a church and administrative center of medieval Bosnia (Skarić, 1937).

The year 1462 was taken for the traditional date of the founding of Sarajevo, and Isa-beg Ishakovic ${ }^{4}$ as its founder. He ordered to build the following profane and sacred objects: The Emperor's Mosque, the Emperor's Bridge, hammam, caravan-saraj with bezistan and shops. The most significant period in the urban development of Sarajevo in the Ottoman period was the 16th century for the reign of Gazi Husrev-beg, ${ }^{5}$ which is rightly referred to as the golden age in the history of this city when Baščaršija was built (Figure 4). In that period, Sarajevo grew from a small kasaba to a large šeher where many wonderful bridges were built.

4 Isa-Beg Ishaković (Turkish: İshakoğlu İsa Bey; fl. 1439-70) was an Ottoman general and the governor of the Sanjak of Bosniafor most of his career. Of Bosnian noble origin, he was recruited after being held hostage by the Ottomans. He was a provincial governor during the 1450s and 1460s, first in charge of the Sanjak of Skopje, and then the Sanjak of Bosnia. He was instrumental in the Ottoman conquests in the region, and was one of the Sultan's most trusted generals (Suljević, 2010).

5 Gazi Husrev-beg (Ottoman Turkish: Gäzī Husrev Beğ; Modern Turkish: Gazi Hüsrev Bey; 1480-1541) was a Bosniak Ottomansanjak-bey (governor) of the Sanjak of Bosnia in 1521-1525, 1526-1534, and 1536-1541. He was known for his major contribution to the improvement of the structural development of Sarajevo urban area and his construction of many important buildings there, such as the Gazi Husrev-beg Mosque or the medresa Kuršumlija, as well as for his successful conquests and for the launching of further Ottoman expansion into Croatia. He was born in Serres, Greece, to a Bosnian Muslim father Ferhad ${ }^{[1]}$ and a Turkish mother Selçuka, who was the daughter of the Sultan Bayezid II, making Gazi Husrev-Beg Beyazid II’s grandson (Šabanović, 1960). 


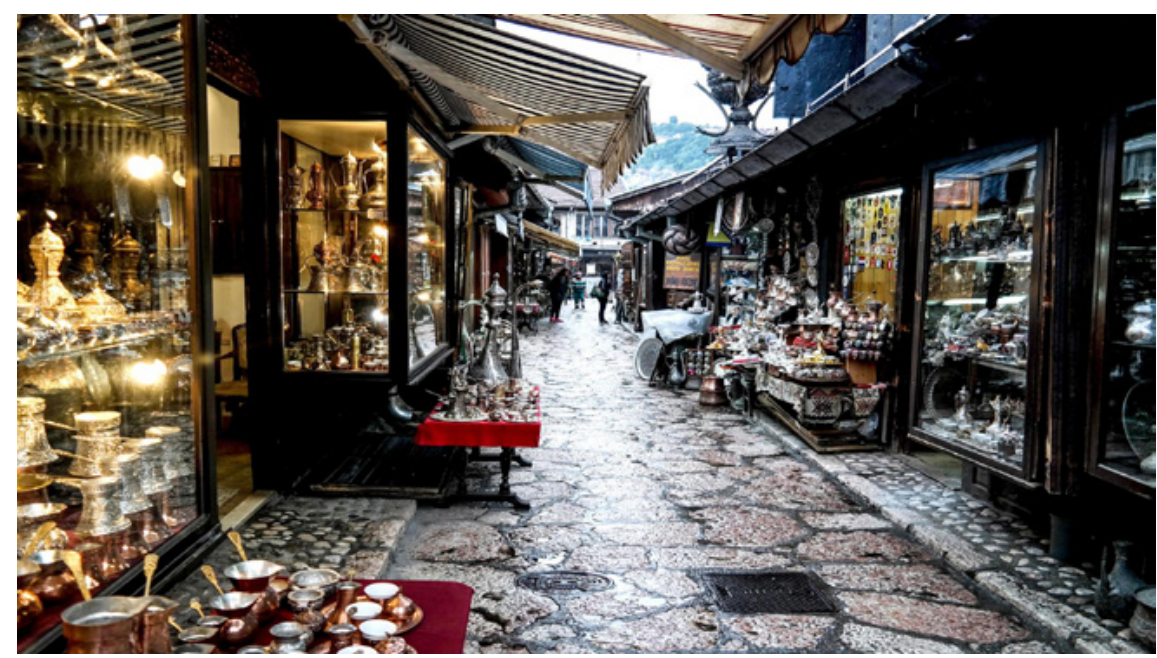

Figure 4: Baščaršija - the old core of the capital of Bosnia and Herzegovina (Photo: author)

The Austro-Hungarian Administration (1878-1918) also had a significant impact on the city. Sarajevo is connected with other parts of the country via the railway line between the Bosnia and Neretva valley, as well as the Miljacka Canyon and further to Višegrad. Then a planned plumbing and sewage system was implemented, electric current and electric public lighting were introduced, the Miljacka riverbed was built and embankment was built on the shore, main roads asphalted, electric tram introduced, etc. (Bidžan, 2008).

The meeting of two civilizations and architectural concepts - Islamic - Oriental until 1878 and Central European or Austro-Hungarian after that, gives a specific color to Sarajevo; historical epochs have left traces on urban units and monuments of residential and sacral architecture, so that today, in the Sarajevo tourist-geographical region, there is an ambient mosaic which increases the interest of domestic and especially foreign tourists. In a relatively small area of this region, numerous monuments of various confessionalities (mosques, churches, cathedrals, synagogues, religious schools) have been preserved, along with business and practical institutions: hans, bezistans, hammams, bridges, fountains, watercourses, libraries, a clock tower, theaters, museums, galleries, etc. If we add the variety of residential buildings (from small from Turkish periods, over large and bigger ones from the Austrian periods to simple skyscrapers of today), as well as various city communications (the curvy cobbled streets from the Ottoman period, asphalted streets and wider streets covered with cobblestone from the Austrian period and wide boulevards in the newest parts of the city), then the mosaic is complete. In 1984, the XIV Winter Olympics were held in this region, which gives another specialty to this area. Along with the traditional type of music - Sevdalinka, new music genres have been developed (pop, schlager music, chanson, jazz, rock'n'roll, heavy metal, hip hop, house, techno) for the last decades in Bosnia and Herzegovina, so we do not lag behind other countries of the world. In this regard, numerous music events are held in Sarajevo tourist-geographical region, such as the International music festival, Jazz fest Sarajevo, Baščaršija nights, Novogradski days, the International folklore festival, etc.

"Since its inception, Sarajevo has had a unique civilization and cultural development in which the charm of the past, spirituality and sociality has become its recognizable code - multiethnicity - multiculturalism - multiconfessionality - coexistence - tolerance. Everywhere and in every place, in the rich luxuries of cultural-historical, religious and other monuments and buildings, the code of the past is recognizable, which is one of the elements of Sarajevo tourist identity". (Nurković et al., 2005).

In this regard, Sarajevo tourist-geographical region is rich in diverse natural and anthropogenic tourist potentials making it very attractive to tourists. Cultural and historical monuments, cultural and architectural heritage, sports, economic, cultural and other events, museums and galleries, and a dynamic and developed relief with many very distinctive features (mountains, canyons, cliffs, caves etc.), specific climate, numerous hydrographic and biogeographical specificities are significant tourist attractions, and the built capacity of tourism infrastructure is a good basis for using these potentials at the current level of socio-economic development. In general, we can say that the tourism potential of this region is characterized by its specific and complementary tourist attributes, which attract tourists to visit it and as such, from a tourist-geographic point of view, can be valued as complete, complex and complementary. 
Sarajevo tourist-geographical region is the center of the road traffic in Bosnia and Herzegovina. Seven major roads link this region to other parts of the country. To the north M-5 towards the Travnik, Banja Luka and Bihać region, M-17 (E73) to the Doboj region, as well as M-18 towards the Tuzla region, to the east M-5 towards the Podrinje region, as well as M-19 (E761). To the south leads M-18 via Podrinje to Dubrovnik, and to the west M-17 (E73) towards the Mostar region. Since 2003, the Sarajevo region is connected via highway A1 to places: Ilijaš, Visoko and Kakanj. The planned European highway, Corridor Vc, runs past Sarajevo, linking it with Budapest in the north and with the Ploće in the south. This tourist-geographic region is also located on a significant railway network: Ploče-MostarSarajevo-Zenica-Doboj-Bos.Šamac-Republic of Croatia and further to Central and Eastern Europe, which is one of the positive elements of tourist infrastructure and tourist product of this region. It also has an international airport, which makes it possible to connect this area with foreign tourists all over the world (Marić, 2008).

As far as tourist traffic is concerned, Sarajevo tourist-geographical region was visited by 482,441 tourists in 2017 , of which $12,4 \%$ were domestic and 87,6\% foreign. In the same year they had 967,204 overnight stays, of which 10,6\% were domestic and 89,4\% foreign. The number of tourist arrivals and overnight stays increases year by year by about $18.4 \%$. Moreover, the number of arrivals and overnight stays of foreign tourists was about 8 times higher than the number of arrivals and overnight stays of domestic tourists. In the year 2017 the most foreign tourists were from Turkey (62,724), Croatia (39,243), United Arab Emirates (25,846), Slovenia (20,067), USA (17,875), Serbia $(17,826)$, China $(16,394)$ and Germany $(15,319)$ (Institute for Statistics of the Federation of Bosnia and Herzegovina, 2018).

This tourist-geographical region belongs to the metropolitan tourist regions and has great importance for defining the tourist offer of Bosnia and Herzegovina, out of a total of 626 national monuments in Bosnia and Herzegovina, in the Sarajevo region there are 95 national monuments. All this characterizes this region as the only metropolitan tourist-geographic region in Bosnia and Herzegovina, but also a unique identity in Southeast Europe and beyond. It is a region characterized by considerable authenticity, representativity, diversity, integrity, landscape-spatial value, which have a great scientific, educational, cultural, historical, social, economic, development, geoecological significance and function (Bidžan, 2015, Bidžan-Gekić et al, 2017).

The world tourist portal of Lonely Planet made a list of the ten most attractive cities in the Eastern Europe and Sarajevo was ranked at the 2 nd position. It should be mentioned that the travel guide book of Lonely Planet in its fifth annual collection of the world's best journeys of Best in Travel 2010, presented the top ten countries, regions, and cities to visit in 2010. In this edition, Sarajevo was also chosen one of the ten cities to visit in 2010 together with the cities as Abu Dhabi, (United Arab Emirates), Istanbul (Turkey), Kyoto (Japan), etc. (Foreign Investment Promotion Agency of Bosnia and Herzegovina, 2010).

\section{VALORIZATION of ARCHITECTURAL HERITAGE FROM the OTTOMAN PERIOD in the SARAJEVO TOURIST- GEOGRAPHICAL REGION}

The architectural heritage of the Ottoman period contributes to the cultivation of space and to the enhancement of its quality for the future development of tourism. It represents significant tourism resources for the development of all forms of cultural tourism both in the Sarajevo tourist-geographic region and throughout Bosnia and Herzegovina (Bidžan-Gekić et al, 2017). Cultural tourism is the most massive specific form of tourism in the world today, so our country needs to develop and improve it as much as possible.

The tourism valuation of its anthropogenic tourism potential, in this case of architectural heritage, is of great importance for planning the development of this cultural tourism. All architectural heritage objects should be included in the tourism valuation process. Many objects have the potential to become a cultural tourism product because they uniquely reflect the history of the place, lifestyle and environment, promote the ethnic tradition of the Sarajevo tourist-geographic region and provide the opportunity for a variety of manifestations. The development of cultural tourism on these grounds has not only material, but also the so-called intangible effects such as awareness raising and caring for their own cultural values, preservation and creation of cultural identity and a positive image and affirmation of this community in the world. It can give a meaning to the present way of life. In this paper, the valorization of the existing architectural heritage from the Ottoman period as anthropogenic tourism potentials was carried out through the presented tourist indicators (see Table 1) and based on them they obtained general tourist values and based on which anthropogenic tourism potentials were ranked. 
The synthesis rating of the attractiveness of the architectural heritage from the Ottoman period of the Sarajevo tourist-geographic region was based on an assessment of their total potential and significance for the development of a mass, exclusive or alternative cultural tourism concept, its specific forms and the entire tourist offer in the analyzed space as well as on a comparative rating of the importance of the tourist potentials of (competing) receptive spaces in the immediate and wider environment. This assessment helps to look at the present and potential development of tourism in this region as well as the most appropriate type of cultural tourism for its development.

Table 1: The architectural heritage of the Ottoman period in the Sarajevo tourist-geographic region

\begin{tabular}{|c|c|c|c|c|c|c|c|c|c|c|c|c|c|c|c|}
\hline \multirow{2}{*}{\multicolumn{2}{|c|}{ ANTHROPOGENIC TOURIST POTENTIALS }} & \multicolumn{14}{|c|}{ TOURIST VALORIZATION } \\
\hline & & 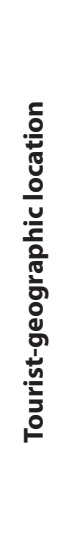 & 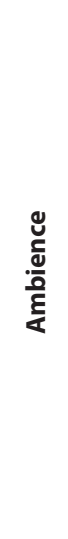 & 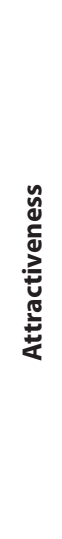 & 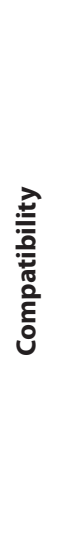 & 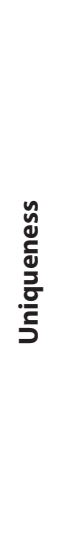 & 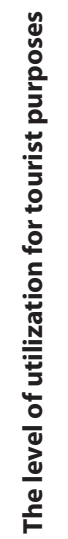 & 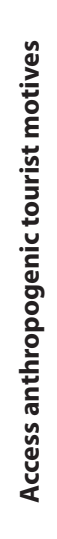 & 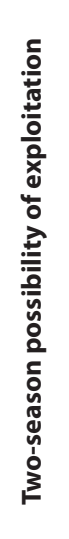 & 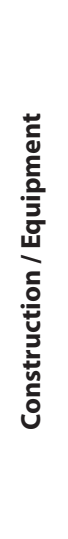 & 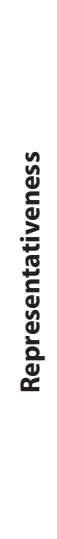 & 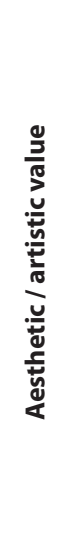 & 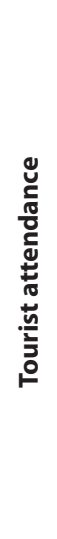 & 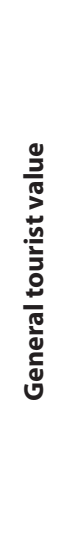 & 兰 \\
\hline \multirow{2}{*}{$\begin{array}{l}\text { Archaeological } \\
\text { locality }\end{array}$} & 1.Atmejdan & 4,5 & 4 & 5 & 5 & 5 & 3 & 4,5 & 4 & 4,5 & 3 & 5 & 3 & 4,2 & $\mathbf{N}$ \\
\hline & 2.Tašlihan & 5 & 5 & 5 & 5 & 5 & 3,5 & 5 & 4 & 4,5 & 3,5 & 5 & 3 & 4,5 & $\mathbf{N}$ \\
\hline \multirow{5}{*}{ 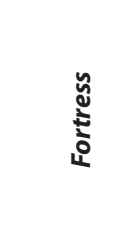 } & 3.Kapi-kule on Ploča & 3 & 3 & 3 & 3 & 3 & 2,5 & 3 & 2 & 3 & 2 & 3 & 2 & 2,7 & $\mathbf{R}$ \\
\hline & 4.Vratnik gate & 4 & 4 & 4 & 4 & 4 & 2,5 & 3 & 2 & 3 & 2 & 3 & 2,5 & 3,2 & $\mathbf{R}$ \\
\hline & 5.Višegrad gate & 4 & 4 & 4 & 4 & 4 & 2,5 & 3 & 2 & 3 & 2 & 3 & 2,5 & 3,2 & $\mathbf{R}$ \\
\hline & 6.Yellow tabia (Jekovačka) & 5 & 4,5 & 4,5 & 4 & 4,5 & 5 & 3 & 3 & 5 & 5 & 5 & 4,5 & 4,4 & $\mathbf{N}$ \\
\hline & 7.White tabia & 3,5 & 4,5 & 4,5 & 4 & 4,5 & 5 & 2 & 2 & 2 & 2 & 5 & 2 & 3,4 & $\mathbf{R}$ \\
\hline \multirow{5}{*}{ 气ั้ } & 8.Roman & 3,5 & 2,5 & 3 & 3 & 4 & 2 & 3 & 3 & 3 & 2 & 3,5 & 2 & 2,9 & $\mathbf{R}$ \\
\hline & 9.Latin & 4,5 & 4 & 5 & 5 & 5 & 3 & 5 & 5 & 5 & 3 & 4 & 4,5 & 4,4 & $\mathbf{N}$ \\
\hline & 10.Kozja & 2,5 & 3,5 & 5 & 5 & 5 & 2 & 2 & 1,5 & 1,5 & 3 & 5 & 2 & 3,2 & $\mathbf{R}$ \\
\hline & 11.Emperor & 4,5 & 4 & 5 & 5 & 5 & 3 & 5 & 5 & 5 & 2 & 4 & 3,5 & 4,3 & $\mathbf{N}$ \\
\hline & 12.Šeher-Ćehaja & 4,5 & 4 & 5 & 5 & 5 & 3 & 5 & 5 & 5 & 2 & 4 & 3,5 & 4,3 & $\mathbf{N}$ \\
\hline \multirow{12}{*}{ 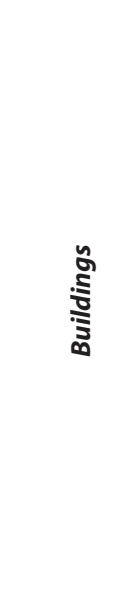 } & 13.Baščaršija & 5 & 5 & 5 & 5 & 5 & 5 & 5 & 5 & 5 & 5 & 5 & 5 & 5,0 & M \\
\hline & 14.Brusa bezistan & 4,5 & 4 & 5 & 5 & 5 & 3 & 5 & 5 & 5 & 3 & 4 & 4,5 & 4,4 & $\mathbf{N}$ \\
\hline & 15.Morića han & 5 & 5 & 5 & 5 & 5 & 4,5 & 5 & 4,5 & 4,5 & 3 & 5 & 4 & 4,6 & M \\
\hline & 16.Inat house & 4,5 & 4 & 5 & 5 & 5 & 3 & 5 & 5 & 5 & 3 & 4 & 4,5 & 4,4 & $\mathbf{N}$ \\
\hline & 17.Clock tower & 5 & 5 & 5 & 5 & 5 & 2 & 5 & 3,5 & 3,5 & 3 & 5 & 2,5 & 4,1 & $\mathbf{N}$ \\
\hline & 18.Gazi Husrev - bey's hamam & 4 & 3,5 & 5 & 5 & 5 & 2 & 2 & 3 & 3 & 3 & 5 & 2 & 3,5 & $\mathbf{R}$ \\
\hline & 19.Gazi Husrev - bey's bezistan & 5 & 5 & 5 & 5 & 5 & 5 & 5 & 5 & 5 & 4 & 5 & 5 & 4,9 & M \\
\hline & 20.Sebilj & 5 & 5 & 5 & 5 & 5 & 5 & 5 & 5 & 5 & 5 & 5 & 5 & 5,0 & M \\
\hline & 21.Saburina's house & 2,5 & 3,5 & 5 & 5 & 5 & 2 & 2 & 1,5 & 1,5 & 3 & 5 & 2 & 3,2 & $\mathbf{R}$ \\
\hline & 22.Alifakovac fountain & 3 & 3,5 & 5 & 5 & 5 & 2 & 2 & 1,5 & 1,5 & 3 & 5 & 2 & 3,2 & $\mathbf{R}$ \\
\hline & 23.Đerzelez's house & 3 & 3,5 & 5 & 5 & 5 & 2 & 2 & 1,5 & 1,5 & 3 & 5 & 2 & 3,2 & $\mathbf{R}$ \\
\hline & 24. Urbanistic structure Saborna church & 5 & 4,5 & 5 & 4 & 5 & 2,5 & 5 & 4 & 2,5 & 2,5 & 5 & 2,5 & 4,0 & $\mathbf{N}$ \\
\hline
\end{tabular}




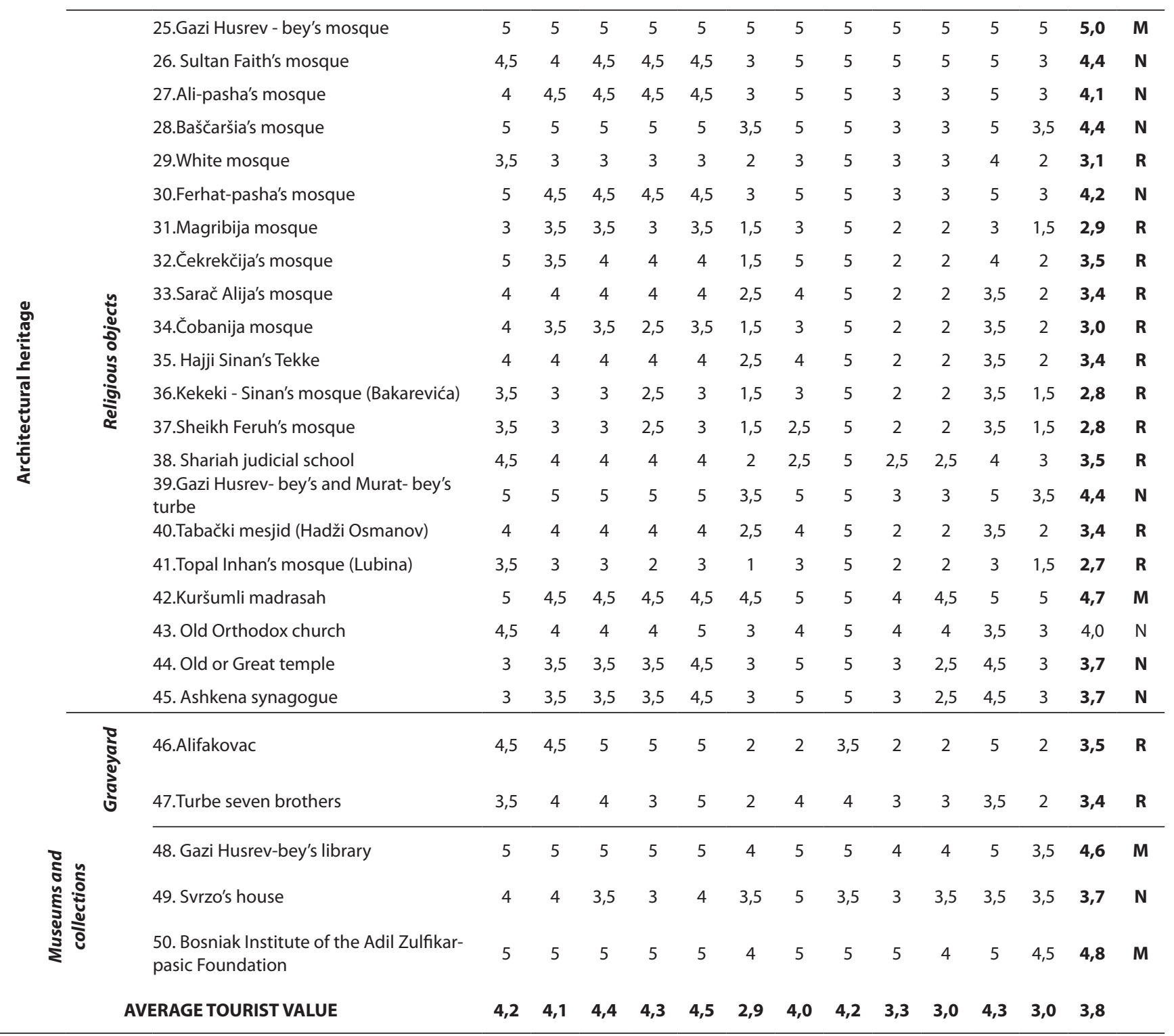

Source: Bidžan, 2015.

The Sarajevo tourist-geographic region according to spatial significance from the Ottoman period has 9 cultural tourism potentials (architectural heritage) of international significance, 18 potentials of national significance, 23 potentials of regional significance, and the number of architectural heritages of local importance is much greater (omitted for the sake of visibility). Of the international significance are the following cultural tourism potentials: Baščaršija, Morića Han, City Hall, Gazi Husrev-bey Bezistan, Sebilj fountain, Gazi Husrev-bey mosque, Kuršumli madrasa, the Church of the Congregation, Gazi Husrev-bey's library, Bosniak Institute of Adil Zulfikarpasic Foundation. The greatest concentration of landmarks that make up the basis of possible tourism products of the Sarajevo tourist-geographic region are located in the narrowest urban center Baščaršija, ie the central parts of the municipalities of Centar and Stari Grad (Old Town), and there are also the inevitable atmospheric and ambiguous entities: Vratnik, Alifakovac, Bistrik etc. (Bidžan, 2015). With the arrival of the Ottomans in the fifteenth century, for the medieval Bosnian state began the period of the new urban and communal development of the cities, ie changes in the religious, linguistic, cultural, political and military aspects, which certainly reflected on the construction industry. Below I will give a brief description of the five highly rated anthropogenic potentials from the Ottoman period in this region. 
Baščaršija is the old Sarajevo bazaar, and the historical and cultural center of the city. Baščaršija was built in the 15th century when Isa-beg Ishaković founded the entire city. Because of the great fire in the XIX century, today's Baščaršija is twice as small as it used to be. It is located on the northern bank of the River Miljacka, in the municipality of Stari Grad Sarajevo. There are several important historical buildings in it: Gazi Husrev-bey mosque, Čaršijska and Ferhadija mosques, Clock Tower, Gazi Husrev-bey's madrasa and library, Sebilj (Figure 5), Morića and Kolobara han (a roadside inn), Brusa and Gazi Husrev-bey bezistan, etc. Nowadays, Baščaršija is the main tourist attraction of the city of Sarajevo, and the entire Sarajevo tourist-geographic region. It was built in 1462, when Isabeg Ishaković built an inn (han), and beside it numerous shops. At that time most of the inhabitants of Sarajevo lived in the vicinity of the Emperor's mosque. That is why Isa-beg Ishaković built a bridge over Miljacka and thus linked the main Sarajevo area and the new economic center of the town, Baščaršija. At that time, most of the inhabitants of Sarajevo lived in the surrounding of the Emperor's Mosque. That is why Isa-beg Ishaković built a bridge over Miljacka and thus connected the main Sarajevo settlement and the new economic center of the city, Baščaršija. A bazaar of Bazerdžana was formed around the main entrance. Towards the west, the Kazaza magnate is formed, and on the north side of the sedges Sedlara and Sarača (today's Sarači street). The most significant buildings built in this period are the mosques. The famous Baščaršija mosque was built by Havedža Durak in 1528 (Bejtić, 1953).

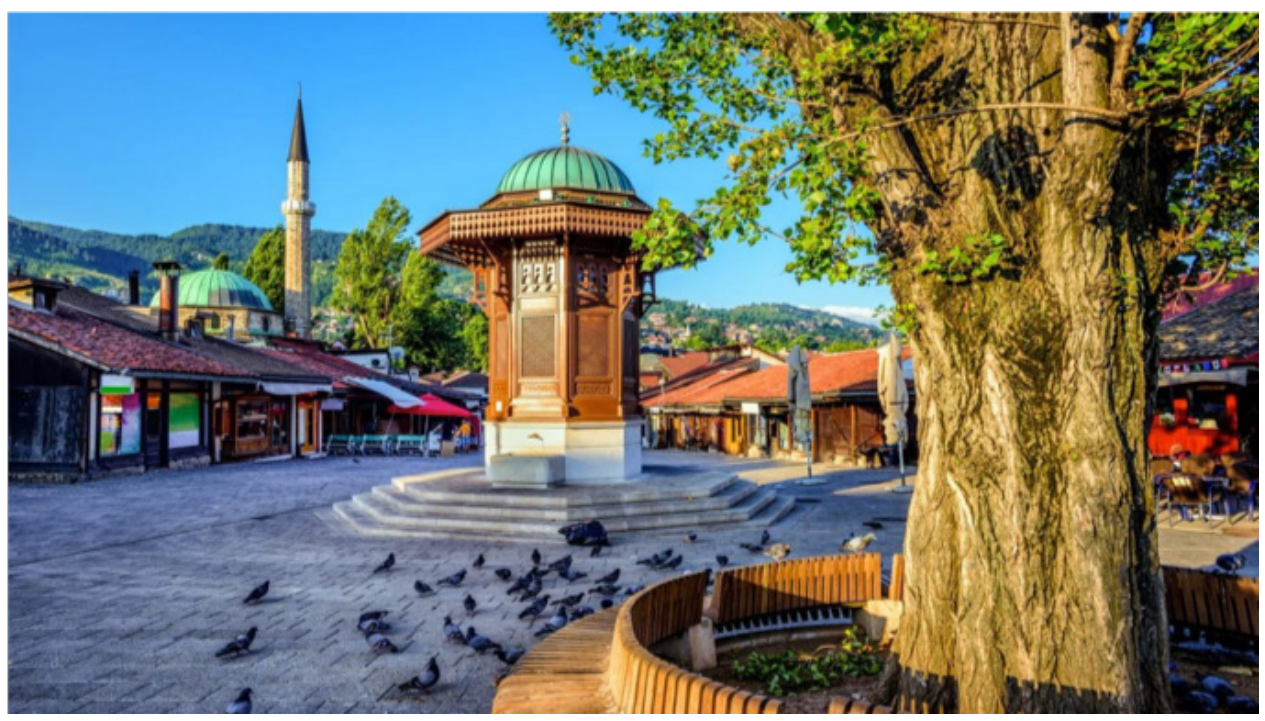

Figure 5: Baščaršija - the old core of Sarajevo

(Photo: author)

The Spatial Plan of Bosnia and Herzegovina (1980) rated and categorized Baščaršija as a locality of 0 (zero) category of international significance (The Spatial Plan of Bosnia and Herzegovina, 1980). The Commission for the Preservation of National Monuments placed Baščaršija on the List of National Monuments of Bosnia and Herzegovina. In the tourist valorization, Baščaršija's highest rating (5 excellent quality and high market attractiveness) was obtained from all tourist rating criteria. The overall tourist value of this national monument is the highest possible and amounts to 5.0, which means that it has an international tourist significance (see table 1).

$>$ The Gazi Husrev-bey's mosque is one of the most prestigious mosques of the early period of the classical style in general, and in Southeast Europe its complex is the most valuable monument of the Ottoman period. "The Gazi Husrev-bey's, or popularly known as the Begova mosque, by its construction, shape, dimensions and decoration, represents a work of special interest in the study of Ottoman architecture in our regions (Figure 6). The mosque has a complex architectural solution. The interior of the mosque is a beautiful stalactite decoration in the corners beneath the domes and in the mihrab itself, as well as ornaments and calligraphy of all the walls. The entire interior of the mosque is decorated with caligraphically printed verses from the Qur'an. 


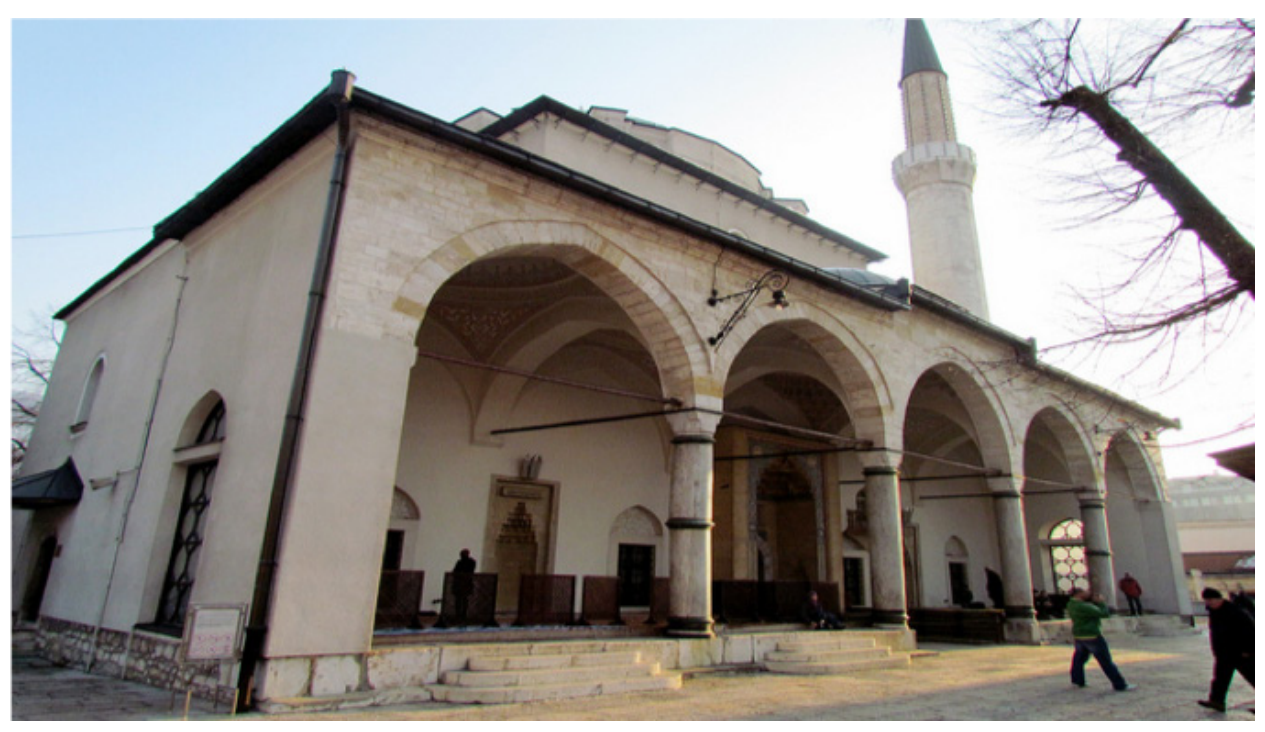

Figure 6: The Gazi Husrev-bey’s mosque

(Photo: author)

The interior of the mosque is covered with precious rags, some of which are the gifts of the rulers of Islamic countries who visited this mosque during their stay in Sarajevo. All the parts of the mosque interior make a harmonious whole with the main space. Minaret is 45 meters high, confirms the virtuosity of the neymar who created the work of permanent artistic value. Five times a day from the mosque's minaret boomes the voice of the muezzin who invites the faithful to prayer, and this call is repeated every day from $1530 / 31$. to this date (Redžić, 1983).

The Spatial Plan of Bosnia and Herzegovina (1980) evaluated and categorized the Begova mosque as a locality of 0 (zero) category, of international significance (The Spatial Plan of Bosnia and Herzegovina, 1980). The Commission for the Preservation of National Monuments placed the Begova mosque on the List of National Monuments of Bosnia and Herzegovina. In the tourist valorization of the Begova mosque, the highest rating (5 - excellent quality and high market attractiveness) was obtained from all tourist rating criteria. The overall tourist value of this national monument is the highest possible and amounts to 5.0, which means that it has an international tourist significance (see table 1).

$>$ The Gazi Husrev-bey's madrasa is especially distinguished among the educational institutions, that was built in 1537 in Sarajevo's tourist-geographic region, due to the lead-roof known also as Kuršumlija and represents a building of great artistic value and also has a good tourist-geographic position (opposite the Gazi Husrev-bey's mosque). It is the only school in Bosnia and Herzegovina, and there is not many in the world, which has been working for over 482 years. This school has educated thousands of people who spread Islamic morality and science among the Bosniak people. The Gazi Husrev-bey's madrasah's building was designed as a polyvalent and representative building in which a central place was given to the dershana (space for classes), and the series of wing rooms had residential character. By the decision of the founder of the madrasah, it was located in the heart of the Baščaršija, and its design entrusted to the leading architect of the Ottoman Empire, Persian Adjemu Esir Ali (Bećirbegović, 1971). It has become one of the symbols of Sarajevo (Figure 7).

The Spatial Plan of Bosnia and Herzegovina (1980) evaluated and categorized Gazi Husrev-bey's Madrasa as a monument of the I (first) category of national significance (the Spatial Plan of Bosnia and Herzegovina, 1980). The Commission for the Preservation of National Monuments placed this madrasah on the List of National Monuments of Bosnia and Herzegovina. In the tourist valorization, Gazi Husrev-bey's madrasah got the highest rating (5 - excellent quality and high market attractiveness) from the criterion: touristgeographic position, access to anthropogenic tourist motives, two-season exploitation opportunities, aesthetic / artistic values and tourist visits, and the lowest rating (4 - very good quality and very good market attractiveness) was obtained from the criteria of construction. The general tourist value of this madrasah is very high and amounts to 4.7, which means that it has an international tourist significance (see table 1). 


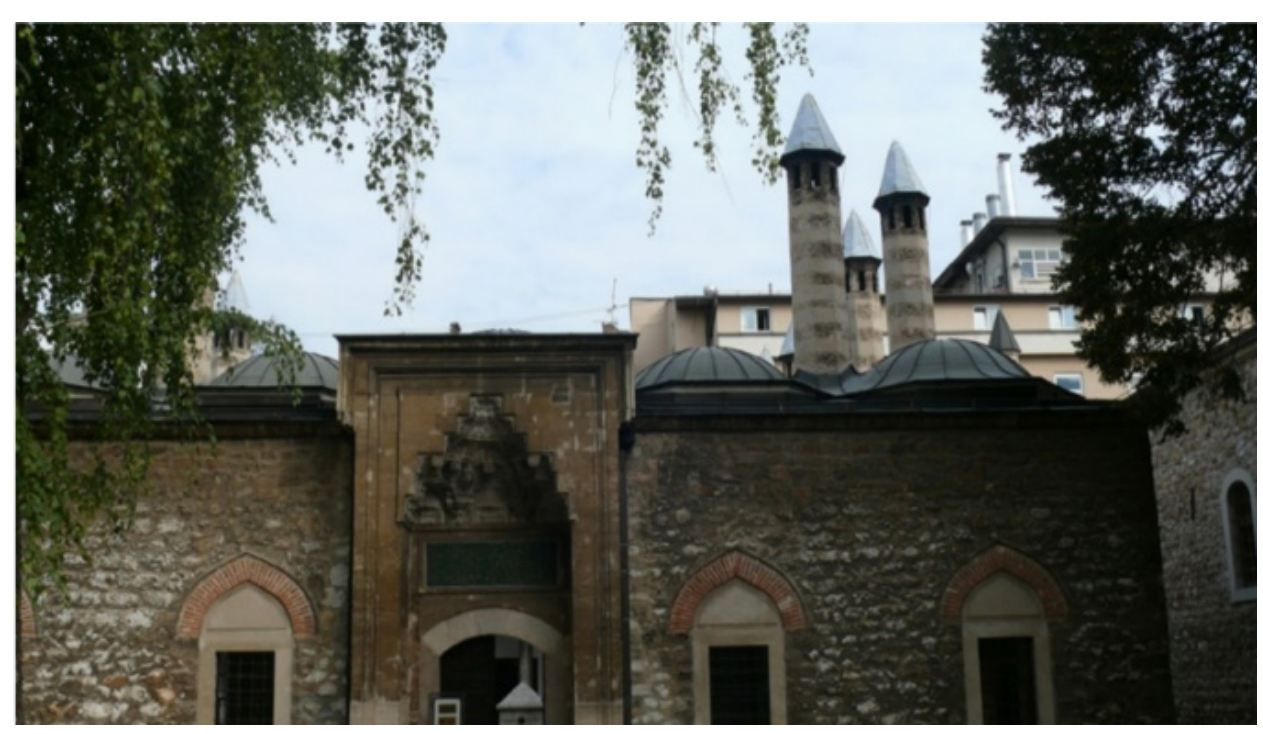

Figure 7: The Gazi Husrev-bey's madrasah

(Photo: author)

- Gazi Husrev-bey's hammam is the most significant tourist domed well-preserved monumental object, which was built in 1555 . Hammam had a female and male department, where Jews' ritual wash basins were built in the nineteenth century. Since 1914, this building, unfortunately, has not served its purpose. Considering that during the war between 1992 and 1995 due to the shelling of Sarajevo, the hammam was significantly damaged, it was assigned to the Bosniak Institute for use for general social purposes, with the obligation for this institute to undertake a thorough reconstruction of the damaged facility by its means. Today, Gazi Husrev-bey's hammam, though with a new purpose, shines again in full glory. In Mula Mustafa Bašeskija Street, across the street from the Sarajevo Cathedral, there is a building covered by two large and eight small cubes. Next to it, during its adaptation, the stores were rebuilt which are mentioned in the description of 1932 by the academic Hamdija Kreševljaković (Redžić, 1983).

The Spatial Plan of Bosnia and Herzegovina (1980) evaluated and categorized the Gazi Husrev-bey hammam as a monument of the I (first) category of national significance (the Spatial Plan of Bosnia and Herzegovina, 1980). The Commission for the Preservation of National Monuments has placed this Hammam on the List of National Monuments of Bosnia and Herzegovina. In the tourism valorization of Gazi Husrev-bey's hammam, highest rating (5 - excellent quality and high market attractiveness) was obtained from the criteria: attractiveness, compatibility, uniqueness and aesthetic / artistic values, and the lowest rating (2 - satisfactory quality and medium market attractiveness) was obtained from the criterion: the degree of utilization for tourist purposes, the access to anthropogenic tourist motifs and tourist attendance. The overall tourist value of this hammam is low and amounts to 3.5, which means that it has a regional tourist significance (see table 1).

Morića han is the only big inn, the caravan-saray, to be preserved to this date in Bosnia and Herzegovina, ie in Sarajevo's touristgeographic region. This inn is an object of Gazi Husrev-beg's vakuf, which was erected in the heart of Sarajevo's bazaar at the end of the 16th or early 17th century, and its authenticity has been preserved to this day (fig.8). Morića han could in his time receive a caravan of 300 passengers and 70 horses (Redžić, 1983). The meetings of the Sarajevo Champions as well as the Sarajevo craftsmen's meetings often took place in this coffeehouse, and Morića han coffeehouse became so significant that it also entered Sevdalinka (a traditional genre of folk music). Today Morića han is the business-shopping center of this waqf. 


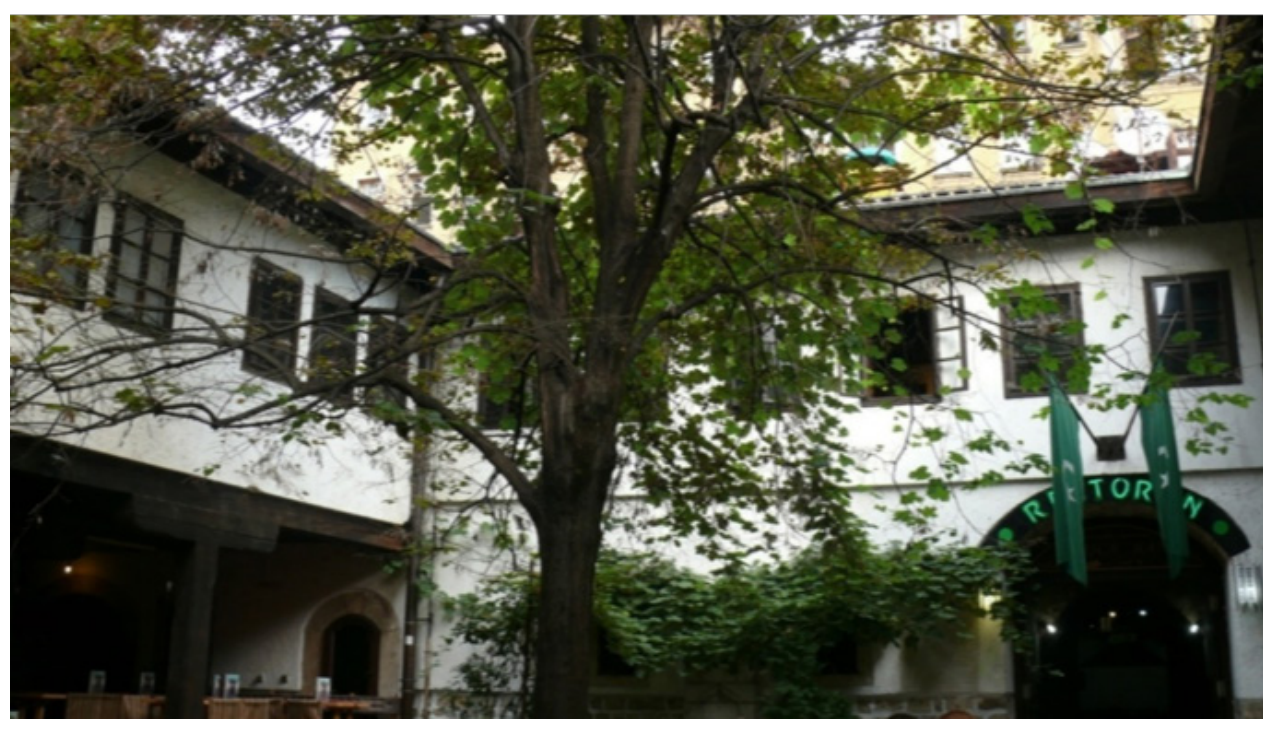

Figure 8: The Morića han

(Photo: author)

The Spatial Plan of Bosnia and Herzegovina (1980) evaluated and categorized Morića han as a monument of the I (first) category of national significance (the Spatial Plan of Bosnia and Herzegovina, 1980). The Commission for the Preservation of National Monuments placed Morića han on the List of National Monuments of Bosnia and Herzegovina. In the tourist valorization of Morić han, the highest rating (5 - excellent quality and high market attractiveness) was obtained from the following criteria: tourist-geographic position, ambience, attractiveness, compatibility, uniqueness, access to anthropogenic tourist motifs and aesthetic / artistic values, and the lowest rating (3 good quality and good market attractiveness) was obtained from the criteria of representativeness. The overall tourist value of this Han is very high and amounts to 4.6, which means it has an international tourist significance (see table 1).

> The Latin bridge overflows the Miljacka river and is located in the immediate vicinity of the At mejdan park and the Sarajevo museum 1878-1918, right next to Sarajevo's bazaar. The Latin bridge, as we see it today, was built in 1798 but in the same place there was a stone bridge before the year 1565 and it was built by some Ali Ajni-bey, who in 1556 managed is Rustem-pasha's property in Sarajevo. Its name was obtained by the Latinluk, settlement on the right bank of the Miljacka river, where Sarajevo Catholics lived, which stretched down the Miljacka to the Ćumurija bridge. In Turkish sources, it was called the Latinluk Frenklul (Franconia) settlement, and the bridge was officially called Frenkluk bridge (Frenklik-küpru) (Kreševljaković, 1991).

The Spatial Plan of Bosnia and Herzegovina (1980) evaluated and categorized the Latin Bridge as a locality of 0 (zero) category of international significance (the Spatial Plan of Bosnia and Herzegovina, 1980). The Commission for the Preservation of National Monuments placed the Latin Bridge on the List of National Monuments of Bosnia and Herzegovina (fig.9). In the tourist valorization, the highest rating (5 - excellent quality and high market attractiveness) was obtained from most of the tourist rating criteria, and the lowest rating (3 - good quality and good market attractiveness) was obtained from the criteria of representativeness and the degree of utilization for tourist purposes. The overall tourist value of this national monument is the highest possible and amounts to 4.4 , which means that it has a national tourist significance (see table 1). 


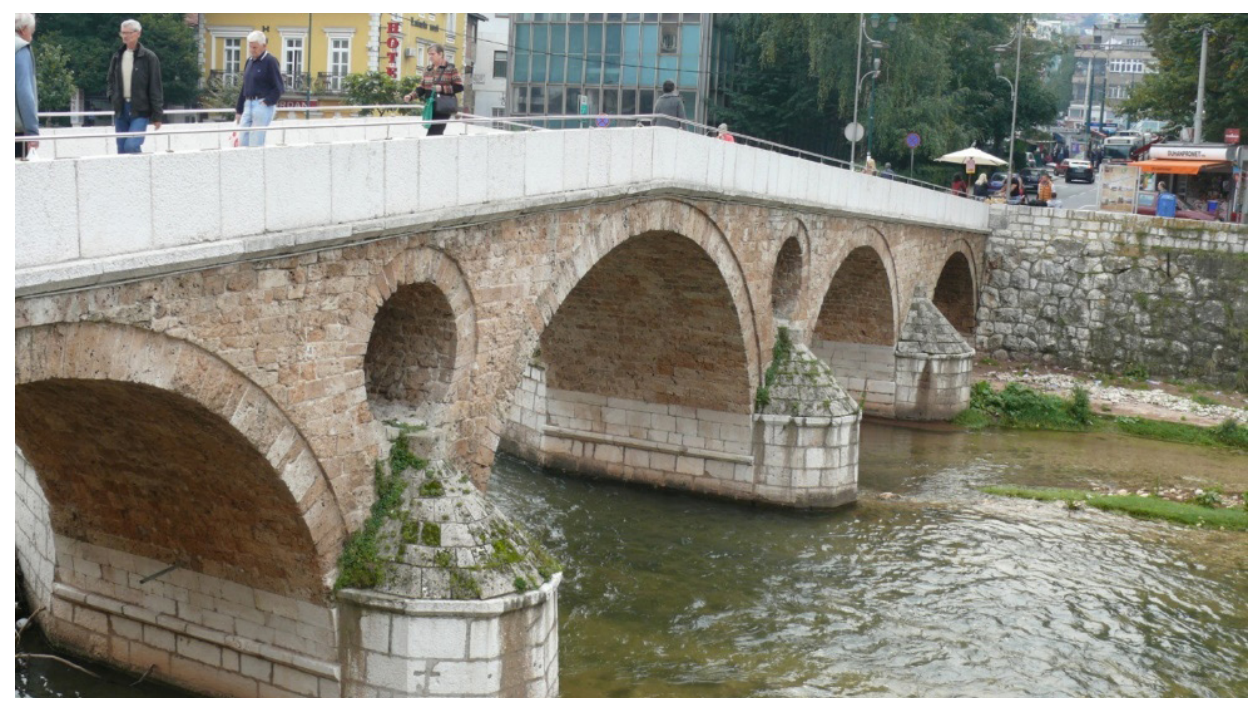

Figure 9: The Latin bridge (Photo: author)

Sarajevo Clock Tower is the most beautiful in Bosnia and Herzegovina. It is located in Sarajevo tourist-geographical region, on the west side of Begova Mosque in the front of Imaret (Bidžan, 2011). It is a square slender tower, which reaches the şerefe (a wraparound balcony of a minaret where the muezzin recites the azaan) of the mosque's minaret. At the top of this tower there is a clock, whose mechanism can be seen from all four sides through the tower's window. It is not known exactly when the clock tower was built, as it is not mentioned in Gazija's Waqfs. The earliest remembrance is in one work of Ćatib Ćelebija, an Ottoman geographer of the first half of XVII century. Among others, he says that there is a clock with a bell at the Husrev-bey's mosque. The upper part of this tower was reconstructed four years before the occupation. On this occasion, the present clock was built, purchased from England. It was brought from London by Sarajevo merchants Hašimaga Glođo and Mehaga Hadžikapetanović. Before that, there was only one opening on the old clock tower, towards the backyard of the Begova mosque, which is still visible today. The clock at the clock tower shows time according to lunar time calculations. Given that the length of a day changes almost daily during a year, and therefore the time of sunset changes as well, this hourly mechanism needs to be constantly adjusted. The clock setting is the duty of the muvekkit who, based on the precise determination of the sunset time, performs the correction of the numerator on the clock tower. When a sunset occurs, this clock tower needs to show 12 o'clock. This clock tower was repaired in 1931 and 1955, and after the war in Bosnia and Herzegovina (1992-95), when it suffered minor damage (Kreševljaković, 1957).

The Spatial Plan of Bosnia and Herzegovina (1980) evaluated and categorized the clock tower as a monument of the I (first) category of national importance (the Spatial Plan of Bosnia and Herzegovina, 1980). The Commission for the Preservation of National Monuments has placed the Sarajevo clock tower on the List of National Monuments of Bosnia and Herzegovina. In the tourism valorization of the Sarajevo clock tower, the highest rating (5 - excellent quality and high market attractiveness) was obtained from the criteria: touristgeographic position, ambience, attractiveness, compatibility, uniqueness, approach to anthropogenic tourist motifs and aesthetic / artistic values, and the lowest rating ( 2 - satisfactory quality and medium market attractiveness) was gained from the criteria of the degree of utilization for tourism purposes. The overall tourist value of this clock tower is 4,1 , which means that it has a national tourist significance (see table 1).

\section{CONCLUSION}

Since anthropogenic tourist potentials represent elements that differentiate individual tourist destinations, so those listed from the Ottoman period also participate in the creation of the tourist identity of the Sarajevo tourist-geographical region. Optimizing their use would have contributed to the strengthening of this identity and would make life more dynamic in this region not only for tourists but also for the local population, and, of course, would make a profit. It is therefore necessary that the Tourist Association of the Sarajevo tourist-geographical region plans to shape all cultural tourism potentials, especially from the Ottoman period. They must first be selected, valorized, then interpreted, where interpretation should be as a creative and interactive process and make the main content of the tourist 
product of this region. This tourism development must also include the preservation of anthropogenic tourist motifs, and thus enable them to maintain time sustainability. The spatial component of the Sarajevo tourist-geographic region is relatively favorable, it is determined by the geopolitical position, of which we emphasize the central position in Bosnia and Herzegovina and the fact that Sarajevo is the capital of Bosnia and Herzegovina, Federation of Bosnia and Herzegovina and the headquarter of the Sarajevo Canton, which represents the political, administrative, economic and cultural center of the country. In this tourist-geographical region, there are all important institutions of the cantonal, federal and state importance, numerous diplomatic-consular, international and other economic representations (BidžanGekić et al, 2017). The Sarajevo tourist-geographical region is an interesting tourist destination, as a result of its geographic position, exceptional and intact natural beauty, cultural-historical values and favorable climatic conditions. This region is characterized by the number and diversity of content, which can largely be included in a tourist offer and at the same time serve the domicile population. The old city core or the new ambience units, as well as specific events, manifestations and atmosphere attract tourists. The adequate state of the mentioned cultural goods, their protection and optimal exploitation represent a prerequisite for inclusion in the tourist offer, which the Sarajevo region can utilize using the appropriate development strategy and at the same time preserve it. Good interpretation and a high-quality cultural tourism product leads to the satisfaction of both tourists and hosts, which will further influence the more balanced local and regional development of other tourist-geographic regions of Bosnia and Herzegovina. 


\section{REFERENCES}

Bejtić, A. (1953). Spomenici osmanske arhitekture u Bosni i Hercegovini. Prilozi za orijentalnu filologiju i istoriju jugoslovenskih naroda pod turskom vladavinom, 3-4, 437-454.

Bećirbegović, M. (1971). Prosvjetni objekti islamske arhitekture u Bosni i Hercegovini. Prilozi za orjentalnu filologiju i istoriju jugoslovenskih naroda pod turskom vladavinom, 20-21, 223-359.

Bidžan, A. (2008). Regionalno-geografski značaj Sarajeva kroz vijekove. Zbornik II Kongresa geografa Bosne i Hercegovine, 665-675.

Bidžan, A. (2011). Turističko-geografsko rejoniranje kao osnova geografske regionalizacije Bosne i Hercegovine. (Unpublished Master thesis). Department of Geography, Faculty of Science, University of Sarajevo, Sarajevo, Bosnia and Herzegovina.

Bidžan A. (2012). Turističko-geografski rejoni Bosne i Hercegovine, Zbornik III Kongresa geografa Bosne i Hercegovine, $496-512$.

Bidžan, A. (2015). Regionalni aspekt vrednovanja turističkih potencijala Bosne i Hercegovine. (Unpublished Doctoral dissertation). Department of Geography, Faculty of Science, University of Sarajevo, Sarajevo, Bosnia and Herzegovina.

Bidžan-Gekić, A., Gekić, H., Nezirović, S. (2017): Cultural tourism impact on the development of Sarajevo tourist-geographical region. Book of Proceedings 2nd International Tourism and Hospitality Management Conference - ITHMC 2016, Sarajevo, 223-237.

Council of Europe (CEO), (1985). viewed 15 May 2019, <https://rm.coe.int/168007a087>

Foreign Investment Promotion Agency of Bosnia and Herzegovina, (2010). viewed 18 May 2019, <http:/fipa.gov.ba /ufokusu/default.aspx?id $=411$ \&langTag=en-US>

Group of authors (1998). Atlas of the World for Primary and Secondary Schools. Sarajevo: Sejtarija.

Group of authors (1980). Spatial Plan of Bosnia and Herzegovina. Phase "B" - Valorization: Natural and Cultural-Historical Values. Sarajevo: Institute of Architecture.

Institute for Statistics of the Federation of Bosnia and Herzegovina, (2013). viewed 22 April $2019<$ http://fzs.ba /index.php/popis-stanovnistva/ popis-stanovnistva-2013/konacni-rezultati-popisa-2013/>

Institute for Statistics of the Federation of Bosnia and Herzegovina, (2018). viewed 19 May $2019<$ http://fzs.ba/wp-content/uploads /2018/07/ Kanton-9-Kanton-Sarajevo.pdf>

International council on monuments and sites (ICOMOS), (2002). viewed 24 April $2019<\mathrm{http} / /$ www.icomos-uk.org/ uploads/sidebar/ PDF/A\%20 Cultural\%20Heritage\%20Manifesto.pdf>

Kreševljaković, H. (1991). Izabrana djela III - banje, vodovodi, hanovi i karavansaraji. Sarajevo: Veselin Masleša.

Lakušić, R. (1981). Klimatogeni ekosistemi Bosne i Hercegovine. Geografski pregled, 25, 41-70.

Law of protect and use of historic-cultural and natural heritage, (2016). viewed 15 May $2019<$ https://www. bastina.ba/index.php/2016-02-29-1006-54/zakon-o-zastiti-i-koristenju-kulturno-historijskog-i-prirodnog-naslijeda>

Lowenthal, D. (2019). viewed 5 June 2019 <https://www.open.edu/openlearn/history-the-arts/history/heritage/what-heritage/content-section-2.1> Marić, Đ. (2008). Saobraćajna geografija. Istočno Sarajevo: Zavod za udžbenike i nastavna sredstva Istočno Sarajevo.

Nurković, S., Mirić, R., Drešković, N., Jahić, H. (2005). Regionalni aspekt turističkih potencijala Kantona Sarajevo - klasifikacija i valorizacija. Zbornik radova "Turizam kao faktor regionalnog razvoja", 31-45.

O’Neil, D. (2006). Culture and Society. Human Culture: What Is Culture?, weblog post 6 May 2006, viewed 15 May $2019<$ https://www2.palomar. edu/anthro/culture/culture_1.htm>

Redžić, H. (1983). Studije o islamskoj arhitektonskoj baštini. Sarajevo: Veselin Masleša.

Skarić, V. (1937). Izabrana djela - Sarajevo i njegova okolina od najstarijih vremena do Austrougarske okupacije. Sarajevo: Veselin Masleša.

Suljević, A. (2010). Gdje je mezar osnivača Sarajeva. Preporodov Journal, 119, 39-40.

Šabanović, H. (1960). Husrev Beg. In: Enciklopedija Jugoslavije, (4, 99-111). Zagreb: Jugoslavenski leksikografski zavod.

UNESCO, (1972). Convention Concerning the Protection of the World Cultural and Natural Heritage, viewed 17 May $2019<$ https://whc.unesco. org/en/conventiontext/>

Zimmermann, K. A. (2017). What Is Culture? Definition of Culture. LiveScience, weblog post 12 July 2017. viewed 15 May $2019<$ https://www. livescience.com/21478-what-is-culture-definition-of-culture.html> 